\title{
Effects of Different Forages in Fermented Total Mixed Rations on Nutrient Utilization and Ruminating Behaviours of Growing Yellow Cattle in Vietnam
}

\section{Dinh Van Dung, Le Dinh Phung*, Le Duc Ngoan, Nguyen Xuan Ba, Nguyen Huu Van, Le Duc THaO}

Faculty of Animal Sciences and Veterinary Medicine, Hue University of Agriculture and Forestry, Hue University, Hue city, Vietnam.

\begin{abstract}
An experiment was conducted to determine effects of forage sources in fermented total mixed rations (FTMR) on feed intake, nutrient digestibility, rumen characteristics and ruminating behaviours of local growing yellow cattle. Four male growing cattle with 12 months of age, initial live weight of $136.1 \pm 9.44 \mathrm{~kg}$ (mean \pm standard deviation) were used in a $4 \times 4$ Latin square design experiment. Treatments were forage sources namely corn foliage (FTMR1), cassava foliage (FTMR2), sugarcane leafy tops (FTMR3) and elephant grass (FTMR4). Forage sources accounted $60 \%$ of FTMR (DM basis). FTMRs were provided ad libitum. The experiment included four periods, 26 days/period; in each period, the first 21 days for adaptation and then 5 days for sample collection. Results showed that, the forage sources in FTMRs had no significant effect $(\mathrm{P}>0.05)$ on the DM intake. However, the forage sources in FTMRs significantly affected $(\mathrm{P}<0.05) \mathrm{DM}$ and $\mathrm{OM}$ digestibilities, whereas $\mathrm{CP}$ and NDF digestibilities were not significantly different among FTMRs $(\mathrm{P}>0.05)$. Forage sources in FMTRs did not affect rumen characteristics $(\mathrm{P}>0.05)$; however, significantly affected ruminating behaviours $(\mathrm{P}<0.05)$. The forage sources in FTMRs significantly affected $(\mathrm{P}<0.05)$ eating rate, ruminating efficiency, chewing efficiency and feed value index. These results indicated that, all forages in this study can be used as main ingredients in FTMRs for cattle production in Vietnam.
\end{abstract}

Keywords | Feed intake, Forage source, FTMR, Ruminating behaviours, Vietnam

Received | September 17, 2019; Accepted | February 17, 2020; Published | March 05, 2020

*Correspondence | Le Dinh Phung, Faculty of Animal Sciences and Veterinary Medicine, Hue University of Agriculture and Forestry, Hue University, Hue city, Vietnam; Email: ldphung@hueuni.edu.vn

Citation | Dung DV, Phung LD, Ngoan LD, Ba NY, Van NH, Thao LD (2020). Effects of different forages in fermented total mixed rations on nutrient utilization and ruminating behaviours of growing yellow cattle in Vietnam. Adv. Anim. Vet. Sci. 8(3): 245-251.

DOI | http://dx.doi.org/10.17582/journal.aavs/2020/8.3.245.251

ISSN (Online) | 2307-8316; ISSN (Print) | 2309-3331

Copyright (C) 2020 Dung et al. This is an open access article distributed under the Creative Commons Attribution License, which permits unrestricted use, distribution, and reproduction in any medium, provided the original work is properly cited.

\section{INTRODUCTION}

$\mathrm{I}^{\mathrm{n}}$ Vietnam, livestock production plays a very important role, not only in providing high value protein products for human consumption, increasing income, improving the living standard of smallholder farmers, but also contributing to crop cultivation by supplying valuable manure (Roubík et al., 2018). Cattle production is one of the most important livestock husbandries for smallholder farmers and has become more and more important in agricultural systems for household livelihoods in Vietnam (Dung et al., 2013). In 2017, the number of beef cattle in Vietnam reached about 5.35 million heads for a total living weight around 231.7 thousand tones, a respective rise of $2.75 \%$ and $4.11 \%$ compared to 2016 (Roubík et al., 2017). However, beef consumption of Vietnamese is still low, only $4.3 \mathrm{~kg} /$ person/year (GSO, 2017). Cattle production in Vietnam is characterised by low growth rate. This is mainly due to the poor feeding regime (Dung et al., 2013).

Vietnam is an agricultural country, with significant amounts of agricultural by-products such as cassava foliage, corn foliage, rice straw, sugarcane leafy tops. Annually, Vietnam has about 5.2 million tons of cassava foliage, 17.7 million tons of corn foliage, 5.6 million tons of sugarcane leafy tops, and many other agricultural by-products (GSO, 2017). All 
these forages are good feed sources for ruminant (Dung et al., 2013). However, the use of those forage sources for ruminant in Vietnam is still limited due to the fact that these forages are highly seasonal availability, while farmers are not used to process and store them for long year around use. Usually from March to July, many agricultural byproducts are not eaten up, but in the rainy season (usually from September to December) the feed for ruminant is not enough (Dung et al., 2013). Previous studies such as Xu et al. (2014), Mirzaei et al. (2018) reported that, different forage sources did not affect feed intake of ruminant. In contrast, Ranathunga et al. (2010) reported that, different forage sources containing different levels of fiber lead to differences in DM intake and nutrient digestibility. The effects of forage sources on nutrient digestibility also are very different among studies. Porter et al. (2007) and Santos et al. (2011) documented that, forage sources had effect on DM digestibility; however, Castells et al. (2012) reported that, DM and OM digestibilities were not affected by different forage sources in diets. Most of studies concluded that using forage sources from agricultural byproducts in ruminant feeding could reduce the cost for animal production and enable efficient utilization of crop residues as potentially useful feed resources (Walli et al., 2012). However, agricultural by-products are characterised by high fiber content and low digestibility. These limit their nutritive values for ruminant (Fon et al., 2012). Quality of forage sources from agricultural by-products should be improved by processing in order to increase their nutritive values for animals, one of the solution is total mixed ration (TMR). There is little information on effects of forage sources in fermented total mixed ration (FMTR) on feed intake, digestibility and ruminant behaviours of cattle.

Therefore, the objective of this study was to evaluate the effects of forage sources from agricultural by-products in FTMRs on feed intake, nutrient digestibility, $\mathrm{pH}, \mathrm{NH}_{3}-\mathrm{N}$ and VFA concentration in the rumen fluid and ruminating behaviours of growing local yellow cattle.

\section{MATERIAL AND METHODS}

The experiment was conducted at the Experimental Farm of Faculty of Animal Sciences and Veterinary Medicine, Hue University of Agriculture and Forestry, Hue University, Thua Thien Hue province ( $16^{\circ} 00^{\prime}$ to $16^{\circ} 48^{\prime}$ latitude, $107^{\circ} 48^{\prime}$ to $108^{\circ} 12^{\prime}$ ' longitude), Vietnam.

\section{ANIMAL, DIET AND EXPERIMENTAL DESIGN}

Four male growing yellow cattle, 12 months of age, with initial live weight of $136.1 \pm 9.44 \mathrm{~kg}$ (mean \pm standard deviation) were used in a $4 \times 4$ Latin square design experiment. Treatments were forage sources namely corn foliage (FTMR1), cassava foliage (FTMR2), sugarcane leafy tops (FTMR3) and elephant grass (FTMR4). All forages were chopped 1-2 cm prior to mixing with brewers' grains, maize meal, cassava meal, soybean meal, salt and premix vitamin-mineral, and the mixture was fermented at least 21 days before feeding the animal. Forage sources accounted $60 \%$ of FTMR (DM basis). The FTMR were provided ad libitum. Cattle were fed three times a day at 07.15, 13.00 and 16.30 hours. The ingredient and chemical composition of FMTR were presented in Table 1.

Table 1: Ingredients and chemical composition of fermented total mixed ration (FTMR).

Item

Treatments $^{1}$

FTMR 1 FTMR 2 FTMR 3 FTMR 4

Ingredient (\% DM basis)

Corn foliage 60

Cassava foliage - 60

Sugarcane leafy

tops

$\begin{array}{lllll}\text { Elephant grass } & - & - & - & 60 \\ \text { Brewers' grain } & 8 & 2 & 5 & 5 \\ \text { Maize meal } & 10 & 17 & 10 & 11 \\ \text { Cassava meal } & 10 & 19 & 7 & 12 \\ \text { Soybean meal } & 10 & 0 & 16 & 10 \\ \text { Premix vita- } & 1 & 1 & 1 & 1\end{array}$

min-mineral ${ }^{2}$

$\begin{array}{lllll}\text { Salt } & 1 & 1 & 1 & 1\end{array}$

Chemical composition (\%DM)

$\begin{array}{lllll}\text { Dry matter } & 39.1 & 42.4 & 44.5 & 38.3 \\ \text { Organic matter } & 92.0 & 90.6 & 93.4 & 92.0 \\ \text { Crude protein } & 13.5 & 14.3 & 12.6 & 12.7 \\ \text { Neutral detergent } & 41.1 & 35.6 & 50.0 & 40.9\end{array}$

fibre

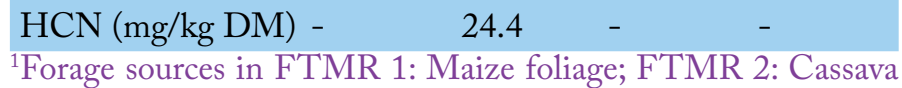
foliage; FTMR 3: Sugarcane leafy tops; FTMR 4: Elephant grass; ${ }^{2}$ Pemix vitamin - mineral: Vitamin A: 3,600,000 UI/kg; vitamin $\mathrm{D}_{3}$ : 300,000 UI/ $\mathrm{kg}$; vitamin $\mathrm{E}: 4,000 \mathrm{mg} / \mathrm{kg}$; vitamin $\mathrm{B}_{1}: 500 \mathrm{mg} / \mathrm{kg}$; vitamin $\mathrm{B}_{2}: 1,000 \mathrm{mg} / \mathrm{kg}$; vitamin $\mathrm{B}_{6}: 650 \mathrm{mg} /$ $\mathrm{kg}$; vitamin $\mathrm{B}_{12}: 6 \mathrm{mg} / \mathrm{kg}$; vitamin $\mathrm{C}$ : $12,000 \mathrm{mg} / \mathrm{kg}$; vitamin $\mathrm{K}_{3}$ : $300 \mathrm{mg} / \mathrm{kg}$; Biotin: $16 \mathrm{mg} / \mathrm{kg}$; Folic acid: $100 \mathrm{mg} / \mathrm{kg}$; vitamin $\mathrm{B}_{5}$ : 2,500 mg/kg; niacin: $5000 \mathrm{mg} / \mathrm{kg}$; Cholin Chloride (Fe, Zn, $\mathrm{Cu}$, $\mathrm{Mn}, \mathrm{Mg}): 40,000 \mathrm{mg} / \mathrm{kg}$.

Each cattle was kept in an individual pen, where water was accessible without restrictions. The experiment consisted of four periods, each period lasted for 26 days. During the first 21 days, all cattle were adapted with their feeds, and the last 5 days was for samples collection. All animals were treated for internal parasites and liver fluke with Bioxinil (Bio Pharmachemie, Ho Chi Minh city) and vaccinated for pasteurellosis with $\mathrm{P} 15$ vaccine $(\mathrm{NaVetCo}$, Ho Chi Minh city), and food and mouth disease prior to the experiment. 
DATA COLLECTION AND SAMPLING PROCEDURES

From days $22^{\text {nd }}$ to $26^{\text {th }}$ of each period, the intake of feed for each cattle was recorded daily and sampled for measuring DM intake and nutrient digestibility. Faeces were quantitatively collected. At the end of each day, total faeces were weighed, thoroughly mixed, subsampled ( $5 \%$ of mixed faeces) and stored at $-20^{\circ} \mathrm{C}$ for later chemical analyses.

The $\mathrm{pH}$ value, $\mathrm{NH}_{3}-\mathrm{N}$ and VFA concentration in the rumen fluid were measured daily from days $25^{\text {th }}$ to $26^{\text {th }}$ of the period. A vacuum-pump machine (MEDI-PUMP, USA) was used to collect rumen fluid via a stomach tube at $7.00 \mathrm{~h}(0 \mathrm{hrs})$ before the morning feeding and $11.00 \mathrm{~h}$ (4hrs after the morning feeding). About $250-300 \mathrm{ml}$ of the rumen fluid was collected each time and the $\mathrm{pH}$ value was measured immediately by a $\mathrm{pH}$ meter (Schott, Germany). Rumen fluid was then filtered through four layers of muslin cloth and a $50 \mathrm{ml}$ subsample of each animal was used to analyze $\mathrm{NH}_{3}-\mathrm{N}$ and VFA concentration.

\section{FeEding beHAVIOUR OBSERVATION METHODS}

The behaviours of individual cattle were recorded by cameras for $48 \mathrm{hrs}$ ( 2 days). The video from cameras was used to analyse the feeding behaviours (eating/ ruminating/resting time). Defecating frequency and urinating frequency were recorded on a plotting paper. The chewing time was calculated by adding the eating time and ruminating time, and the feed value index was calculated based on the chewing time per unit DM intake (Lee at al., 2010). The eating, ruminating and chewing efficiencies were calculated by dividing the DM intake by the eating, ruminating and chewing time, respectively. Chewing time= Eating time + Ruminating time; Eating rate $=\mathrm{DM}$ intake $(\mathrm{g} / \mathrm{d}) /$ eating time $(\mathrm{h} / \mathrm{d})$; Ruminating efficiency= DM intake $(\mathrm{g} / \mathrm{d}) /$ ruminating time $(\mathrm{h} / \mathrm{d})$; Chewing efficiency= $\mathrm{DM}$ intake $(\mathrm{g} / \mathrm{d}) /$ chewing time $(\mathrm{h} / \mathrm{d})$; And feed value index $=$ Chewing time $/ \mathrm{DM}$ intake $(1 \mathrm{~kg})$ (Lee at al., 2010).

\section{Chemical analyses}

Samples of feeds and faeces were dried at $60^{\circ} \mathrm{C}$ and ground (1 mm screen using the Retsche, Germany) and analyzed using standard methods of AOAC (1990) for DM and ash. NDF was determined as described by Van Soest et al. (1991). Total $\mathrm{N}$ was determined according to AOAC (1990) and the concentration of CP was calculated as $\mathrm{N} \times 6.25$.

Rumen fluid was immediately measured for $\mathrm{pH}$ using a $\mathrm{pH}$ meter (Schott, Germany). The $\mathrm{NH}_{3}-\mathrm{N}$ concentration of the rumen fluid was measured by the Kjeldahl method (AOAC, 1990). VFAs were measured by gas chromatography in the Lab of Okayama University, Japan.

\section{STATISTICAL ANALYSES}

All data were statistically analyzed for a Latin square design using the General Linear Models procedure of SPSS 16.0.
Data were analyzed using the following model:

$$
Y_{i j k}=\mu+T_{i}+C_{j}+R_{k}+e_{i j k}
$$

Where; $Y_{\mathrm{ijk}}$ is the dependent variables, receiving treatment $\mathrm{i}$; animal $\mathrm{j}$; period $\mathrm{k}$; $\mu$ is the overall of mean; $T_{i}$ is the effect of treatment $\mathrm{i}(\mathrm{i}=1=\mathrm{FTMR} 1 ; \mathrm{i}=2=$ =FMTR $2 ; \mathrm{i}=3=\mathrm{FMTR}$ 3 and $i=4=F M T R ~ 4) ; C_{j}$ is the effect of animal $j ; R_{k}$ is the period effect; $e_{i j k}$ is the residual effect. The differences between means were compared using a least significant difference method (LSD). Statistical difference was declared at $\mathrm{P}<0.05$.

\section{RESULTS}

\section{FEed INTAKE AND DigeSTIBILITY}

The forage sources in FTMRs had no significant effect $(\mathrm{P}>0.05)$ on the DM intake (both in kilograms per day and percentage of the body weight). However, the forage sources in FMTRs significantly affected DM and $\mathrm{OM}$ digestibilities $(\mathrm{P}<0.05)$, whereas $\mathrm{CP}$ and NDF digestibilities were not significantly affected $(\mathrm{P}>0.05)$ by forage sources in FMTRs (Table 2).

\section{$\mathrm{PH}, \mathrm{N}-\mathrm{NH}_{3}$ AND VFA CONCENTRATION IN RUMEN} FLUID

Different forage sources in FMTRs did not affect the rumen $\mathrm{pH}$ at $0 \mathrm{hrs}$ and at $4 \mathrm{hrs}$ after feeding $(\mathrm{P}>0.05)$. Similarly, $\mathrm{N}-\mathrm{NH}_{3}$ and VFA were not significantly affected $(\mathrm{P}>0.05)$ by different forage sources in FTMRs (Table 3$)$.

\section{RUMINATING BEHAVIOURS}

Ruminating behaviours (eating time, ruminating time and chewing time) were significantly affected $(\mathrm{P}<0.05)$ by different forage sources in FTMRs. However, forage sources in FMTRs did not significantly affect defecating frequency and urinating frequency $(\mathrm{P}>0.05)$. The forage sources in FTMRs significantly affected $(\mathrm{P}<0.05)$ eating rate, ruminating efficiency, chewing efficiency and feed value index (Table 4).

\section{DISCUSSION}

Results of the present study showed that, forage sources in FTMRs had no significant effects on the DM intake. This result was in agreement with $\mathrm{Xu}$ et al. (2014) and Mirzaei et al. (2018). In contrast, Ranathunga et al. (2010) reported that, different forage sources containing different levels of fibre characteristics result different DM intake. In our study, the forages used were chopped at $1-2 \mathrm{~cm}$ and naturally fermented with concentrate for at least 21 days before animal feeding, which can explain the present results. DM intake of cattle ranged from 2.29 to $2.67 \%$ of $\mathrm{BW}$, which are in the range of the feed intake suggested 
Table 2: Dry matter intake and nutrient digestibility of cattle fed different forage sources in fermented total mixed ration (FTMR).

\begin{tabular}{lllcllll} 
Item & & \multicolumn{3}{c}{ Treatments } & SEM $^{1}$ & P \\
& FTMR 1 & FTMR 2 & FTMR 3 & FTMR 4 & & \\
Dry matter intake & & & & & & \\
kg/day & 3.91 & 4.24 & 3.32 & 3.49 & 0.271 & 0.173 \\
\% Body weight & 2.51 & 2.67 & 2.29 & 2.45 & 0.160 & 0.176 \\
Digestibility (\%) & & & & & & \\
Dry matter & $63.1^{\mathrm{ab}}$ & $66.8^{\mathrm{b}}$ & $60.4^{\mathrm{a}}$ & $67.4^{\mathrm{b}}$ & 1.154 & 0.015 \\
Organic matter & $65.9^{\mathrm{ab}}$ & $67.7^{\mathrm{bc}}$ & $62.9^{\mathrm{a}}$ & $69.3^{\mathrm{c}}$ & 0.961 & 0.016 \\
Crude protein & 65.2 & 67.1 & 60.1 & 66.4 & 1.661 & 0.083 \\
Neutral detergent fibre & 51.1 & 52.6 & 51.7 & 54.4 & 2.210 & 0.744
\end{tabular}

${ }^{1} \mathrm{SEM}$ : Standard error of the mean with $\mathrm{df}$ error $=6{ }^{\mathrm{a}, \mathrm{b}, \mathrm{b}, \mathrm{d}}$ Values on the same row with different superscripts $\operatorname{differ}(\mathrm{P}<0.05)$.

Table 3: $\mathrm{pH}, \mathrm{N}-\mathrm{NH}_{3}$ and VFA concentration in the rumen fluid of cattle fed different forage sources in fermented total mixed ration (FTMR).

\begin{tabular}{|c|c|c|c|c|c|c|}
\hline \multirow[t]{2}{*}{ Item } & \multicolumn{4}{|c|}{ Treatments } & \multirow[t]{2}{*}{ SEM $^{1}$} & \multirow[t]{2}{*}{$\mathbf{P}$} \\
\hline & FTMR 1 & FTMR 2 & FTMR 3 & FTMR 4 & & \\
\hline $\mathrm{pH}$ at $\mathrm{Ohrs}$ & 7.12 & 7.00 & 6.82 & 6.97 & 0.124 & 0.456 \\
\hline $\mathrm{pH}$ at $4 \mathrm{hrs}$ & 6.60 & 6.90 & 6.88 & 6.63 & 0.141 & 0.374 \\
\hline $\mathrm{N}-\mathrm{NH}_{3}$ at $0 \mathrm{hrs}(\mathrm{mg} / \mathrm{dl})$ & 7.11 & 6.76 & 7.56 & 7.11 & 0.471 & 0.702 \\
\hline $\mathrm{N}-\mathrm{NH}_{3}$ at $4 \mathrm{hrs}(\mathrm{mg} / \mathrm{dl})$ & 12.89 & 7.60 & 12.51 & 10.78 & 2.133 & 0.364 \\
\hline \multicolumn{7}{|l|}{ VFAs at $0 \mathrm{hrs}(\mathrm{mmol})$} \\
\hline Propionic & 10.06 & 11.56 & 9.18 & 10.32 & 1.184 & 0.592 \\
\hline Acetic & 32.64 & 32.53 & 31.68 & 34.89 & 6.245 & 0.985 \\
\hline Butyric & 4.37 & 10.16 & 4.95 & 5.52 & 1.143 & 0.050 \\
\hline Acetic/propionic & 3.22 & 2.73 & 3.39 & 3.49 & 0.502 & 0.725 \\
\hline \multicolumn{7}{|l|}{ VFAs at $4 \mathrm{hrs}(\mathrm{mmol})$} \\
\hline Propionic & 15.08 & 17.47 & 14.68 & 22.63 & 2.987 & 0.308 \\
\hline Acetic & 38.73 & 43.90 & 42.06 & 62.47 & 7.444 & 0.208 \\
\hline Butyric & 5.78 & 7.39 & 5.98 & 9.57 & 1.323 & 0.258 \\
\hline Acetic/propionic & 2.57 & 2.51 & 2.86 & 2.76 & 0.455 & 0.987 \\
\hline
\end{tabular}

${ }^{1} \mathrm{SEM}$ : Standard error of the mean with df error $=6$.

Table 4: Ruminating behaviors of cattle fed different forage sources in fermented total mixed ration (FTMR).

\begin{tabular}{|c|c|c|c|c|c|c|}
\hline \multirow[t]{2}{*}{ Item } & \multicolumn{4}{|c|}{ Treatments } & \multirow[t]{2}{*}{ SEM $^{1}$} & \multirow[t]{2}{*}{$\mathbf{P}$} \\
\hline & FTMR 1 & FTMR 2 & FTMR 3 & FTMR 4 & & \\
\hline Eating time $(\mathrm{min} / \mathrm{d})$ & $284.2^{\mathrm{a}}$ & $222.2^{\mathrm{b}}$ & $425.7^{c}$ & $310.7^{\mathrm{d}}$ & 6.625 & $<0.001$ \\
\hline Ruminating time (min/d) & $294.0^{a}$ & $254.3^{\mathrm{a}}$ & $442.5^{\mathrm{b}}$ & $281.7^{\mathrm{a}}$ & 16.43 & 0.001 \\
\hline Resting time $(\mathrm{min} / \mathrm{d})$ & $861.8^{\mathrm{a}}$ & $963.4^{\mathrm{b}}$ & $571.5^{c}$ & $847.6^{a}$ & 16.99 & $<0.001$ \\
\hline Total time $(\mathrm{min} / \mathrm{d})$ & 1440 & 1440 & 1440 & 1440 & - & - \\
\hline Chewing time $(\mathrm{min} / \mathrm{d})$ & $578.2^{\mathrm{a}}$ & $476.6^{\mathrm{b}}$ & $868.2^{c}$ & $592.4^{\mathrm{a}}$ & 16.99 & $<0.001$ \\
\hline Defecating frequency (no./d) & 9.22 & 10.39 & 9.31 & 8.06 & 0.417 & 0.072 \\
\hline Urinating frequency (no./d) & 16.11 & 9.05 & 13.59 & 14.94 & 3.120 & 0.415 \\
\hline Eating rate & $827.0^{a}$ & $1151.2^{\mathrm{b}}$ & $470.3^{c}$ & $677.3^{\mathrm{ac}}$ & 62.58 & 0.001 \\
\hline Ruminating efficiency & $795.5^{\mathrm{ab}}$ & $1015.9^{\mathrm{b}}$ & $456.7^{c}$ & $752.8^{\mathrm{a}}$ & 72.44 & 0.009 \\
\hline Chewing efficiency & $405.1^{\mathrm{a}}$ & $534.5^{\mathrm{b}}$ & $231.6^{c}$ & $356.2^{\mathrm{a}}$ & 30.42 & 0.002 \\
\hline Feed value index (min/kg DM) & $151.2^{\mathrm{a}}$ & $112.5^{\mathrm{c}}$ & $268.8^{c}$ & $170.9^{a}$ & 9.73 & 0.006 \\
\hline
\end{tabular}

${ }^{1} \mathrm{SEM}$ : Standard error of the mean with df error $=6$. a,b,d Values on the same row with different superscripts $\operatorname{differ}(\mathrm{P}<0.05)$. 
by Kearl (1982). These results indicate that cassava foliage, corn foliage, sugarcane leafy tops and elephant grass are good forage sources in FMTRs for ruminants.

The digestibilities of $\mathrm{DM}$ and $\mathrm{OM}$ were significantly different among forage sources in FMTRs, lowest in the FMTR with sugarcane leafy tops as forage and such results are in agreement with previous studies (Porter et al., 2007; Santos et al., 2011; Ozcan and Kilic, 2018). Porter et al. (2007) documented that, DM digestibility in animal fed a high NDF level in diets was lower than that in animal fed a low NDF level in diets. The FMTR with sugarcane leafy tops in the present study had NDF content higher than that in other FMTRs; this may explain the lower DM digestibility as well as lower DM intake. These observations are also in agreement with findings of Santos et al. (2011). However, these observations varied from other research of Castells et al. (2012), who reported that, DM and OM digestibilities were not affected by different forage sources. Similarly, Xu et al. (2014) recommended that, different forage sources did not affect DM and OM digestibilities. NDF digestibility was not significantly affected by forage sources in FMTRs, as per the finding of Castells et al. (2012). In contrast, Santos et al. (2011), Xu et al. (2014), De Souza et al. (2018) reported that, NDF digestibility was significantly affected by forage sources. Similarly, NDF and CP digestibilities also were not significantly affected by forage sources. This observation agrees with findings of Xu et al. (2014), who confirmed that forage sources did not affect CP digestibility. However, Castells et al. (2012), Santos et al. (2011) reported that different forage sources significantly affected CP digestibility. Based on above discussion, the effects of forage sources on the digestibility of nutrients varies, depending on factors such as forage types, chemical composition contents, processing methods and animal condition.

The $\mathrm{pH}$ value, $\mathrm{N}-\mathrm{NH}_{3}$ and VFA concentration of the rumen fluid were not significantly affected by forage sources. These findings are consistent with previous studies, such as Eastridge et al. (2009) and Xu et al. (2014), who documented that, the rumen fermentation characteristics were not affected by the forage sources. Similarly, Mirzaei et al. (2018) reported that, rumen $\mathrm{pH}$ of calves was not significantly affected by forage sources, $\mathrm{pH}$ ranged from 5.94 to 5.97. Maktabi et al. (2016) observed similar ruminal $\mathrm{pH}$ levels in dairy calves fed finely ground starter feeds supplemented with different forage sources. In the present study, ruminal $\mathrm{pH}$ ranged from 6.82 to 7.12 , which was sufficient for the maintenance of rumen function. $\mathrm{NH}_{3}-\mathrm{N}$ concentration in the rumen fluid of our study ranged from 6.76 to $12.89 \mathrm{mg} / \mathrm{dL}$, apparently confirming McDonald et al. (1995) results, who concluded that optimal $\mathrm{NH}_{3}-\mathrm{N}$ concentration in the rumen fluid is above $5 \mathrm{mg} / \mathrm{dL}$ in order to improve the rumen ecology, microbial protein synthesis, digestibility and voluntary feed intake. The different forage sources did not affect individual VFA (acetic, propionic and butyric). This observation agrees with the finding of $\mathrm{Xu}$ et al. (2014). When rumen fermentation conditions are optimal, the acetate to propionate ratio should be greater than 2.1:1 (McDonald et al., 1995). In our study, acetate to propionate ratios were within the conditions of optimal fermentation.

Ruminating behaviours (eating time, ruminating time and chewing time) were significantly affected by different forage sources in FTMRs. Chewing time (eating time + ruminating time) was longest in the FMTR 3, which forage source is sugarcane leafy tops $(868.2 \mathrm{~min} / \mathrm{d})$ and shortest in FTMR 2, which forage source is cassava foliage (476.6 $\mathrm{min} / \mathrm{d}$ ). Many previous researchers concluded that, eating time and chewing time of cattle were affected by particles of forage. Chewing time of cattle was longer when fed contained longer particles of the forage. In the present study, all forage was chopped $1-2 \mathrm{~cm}$ before mixing with concentrate then fermented for 21 days prior feeding the animal. Particles of forage sources in the present study could be similar. The significant difference of chewing time in the present study may be due to different NDF content in FTMRs. Beauchemin and Buchanan (1989), Lee et al. (2010) and Carlson et al. (2014) reported that, the higher the NDF content, the longer the ruminating time as well as chewing time. In present results, NDF content was higher in FTMR 3 than other treatments, and it is believed that this was what caused the longer chewing time. Chewing time in the present study was in the following order: FMTR 3>FTMR 4>FTMR $1>$ FMTR 2. For frequency of defecation and urination, there were no significant differences among treatments. Lee et al. (2010) recommended that, the more frequent defecation and urination in cattle fed more DM intake and more wet property of the diet. In the present study, DM intake of cattle and DM content in FTMRs were similar, which could be the cause for frequent defecation and urination in cattle was similar among treatments. Eating rate, ruminating efficiency and chewing efficiency were significantly affected by different forage sources in FMTR and were in the order of FTMR $2>$ FMTR 1>FMTR 4>FMTR 3. Schulze et al. (2014) concluded that, eating rate and chewing efficiency were significantly affected by NDF levels in diets. The different NDF contents in FMTRs in the present study contributed to different eating time, ruminating time and chewing time, these results would be the causative factors towards the different eating rate, ruminating and chewing efficiency. Feed value index was highest in FTMR 3, which forage source is sugarcane leafy tops and significant difference compared to other treatments. The difference of chewing time was causing of the different feed value index. 


\section{CONCLUSION}

Different forage sources in FMTRs did not affect $\mathrm{DM}$ intake, digestibilities of $\mathrm{CP}$ and NDF and rumen characteristics. However, DM and $\mathrm{OM}$ digestibilities, ruminating behaviours, eating rate, ruminating and chewing efficiency were significantly affected by different forage sources in FMTRs. It could be recommended that, all forages in the present study should be used as ingredient in FMTRs for cattle in Vietnam.

\section{ACKNOWLEDGMENTS}

The authors thank the Mekong Basin Animal Research Network (MEKARN II) project for financially supporting this research.

\section{CONFLICT OF INTEREST}

The authors declare that they have no conflict of interest.

\section{AUTHORS CONTRIBUTION}

Writing the manuscript, designing experiments, Data collection, Data analyses: Dinh Van Dung.

Designing Experiments, Revising the manuscript, Data analyses: Le Dinh Phung.

Giving comments on the manuscript: Le Duc Ngoan Giving comments on the manuscript: Nguyen Xuan Ba. Giving comments on the manuscript: Nguyen Huu Van. Giving comments on the manuscript: Le Duc Thao.

\section{REFERENCES}

-AOAC (1990). Association of Official Analytical Chemists. Official methods of analysis. $15^{\text {th }}$ ed. AOAC International, Arlington, UA, USA.

- GSO (2017). General statistics office. Statistical yearbook of Vietnam. Statistical publishing house, Ha Noi.

- Beauchemin KA, Buchanan JGS (1989). Effects of dietary neutral detergent fiber concentration and supplementary long hay on chewing activities and milk production of dairy cows. J. Dairy Sci. 72(9): 2288-2300. https://doi. org/10.3168/jds.S0022-0302(89)79360-7

- Buddanoi R, Abrar A, Wachirapakorn C (2017). Effect of maize stover in fermented total mixed ration on nutritive value and digestibility quality in vitro. J. Peternakan. Sriwi. 6(1): 44-51. https://doi.org/10.33230/JPS.6.1.2017.5078

- Carlson ZE, Gilbery TC, Islas A, Bauer ML, Swanson KC (2014). Influence of forage source on growth performance, feeding behavior and carcass characteristics in finishing steers. North Dakota Beef Report, pp. 15-18.

- Castells LI, Bach A, Araujo G, Montoro C, Terré M (2012). Effect of different forage sources on performance and feeding behavior of Holstein calves. J. Dairy Sci. 95: 286293. https://doi.org/10.3168/jds.2011-4405

- De Souza RA, Tempelman RJ, Allen MS, Weiss WP, Bernard
JK, VandeHaar MJ (2018). Predicting nutrient digestibility in high-producing dairy cows. J. Dairy Sci. 101: 1123-1135. https://doi.org/10.3168/jds.2017-13344

-Dung DV, Wen Y, Ba NX, Kaldoro DH (2013). Feeding system of fattening cattle on smallholder farms in Central Vietnam. Lives Res for Rural Develop. 25(8): Pages. http://www.lrrd. org/.

-Eastridge ML, Bucci PB, Ribeiro CVDM (2009). Feeding equivalent concentrations of forage neutral detergent fiber from alfalfa hay, grass hay, wheat straw, and whole cottonseed in corn silage based diets to lactating cows. Anim. Feed Sci. Techno. 150: 86-94. https://doi.org/10.1016/j. anifeedsci.2008.08.008

- Fon FN, Nsahlai IV (2012). The in vitro fermentation of maize stover as affected by faecal bacteria obtained from ungulates. S. Afri. J. Anim. Sci. 42(5): 478-482. https://doi. org/10.4314/sajas.v42i5.7

- Kearl LC (1982). Nutrient requirements of ruminants in development countries. International feedstuffs institude, Utah Agricultural experiment station, Utah State Univ., Loga, Utah, USA.

-Lee S, Kim Y, Oh Y, Kwak W (2010). Effects of feeding methods of total mixed ration on behavior patterns of growing Hanwoo steers. Asian-Aust. J. Anim. Sci. 23(11): 1469-1475. https://doi.org/10.5713/ajas.2010.10100

- Maktabi H, Ghasemi E, Khorvash M (2016). Effects of substituting grain with forage or nonforage fiber source on growth performance, rumen fermentation, and chewing activity of dairy calves. Anim. Feed Sci. Techno. 221: 70-78. https://doi.org/10.1016/j.anifeedsci.2016.08.024

- McDonald P, Edwards RA, Greenhalgh JFD, Morgan CA (1995). Animal nutrition. Longman Singapore Publisher (Pte) Ltd., Singapore.

- Mirzaei HO, Azarfar A, Mirzaei M, Kiani A, Ghaffari MH (2018). Effects of forage source and forage particle size as a free-choice provision on growth performance, rumen fermentation, and behavior of dairy calves fed texturized starters. J. Dairy Sci. 101: 1-15. https://doi.org/10.3168/ jds.2017-13990

- Ozcan U, Kilic U (2018). Effect of additives on the forage quality of pelleted Hazelnut husks. Asian J. Anim. Ve.t Adv. 13(2): 189-196. https://doi.org/10.3923/ajava.2018.189.196

- Porter JC, Warner RG, Kertz AF (2007). Effect of fiber level and physical form of starter on growth and development of dairy calves fed no forage. Prof. Anim. Sci. 23: 395-400. https://doi.org/10.15232/S1080-7446(15)30994-3

- Rajamma K, Kumar DS, Rao ER, Nath DN (2014). Effect of feeding total mixed rations supplemented with or without exogenous fibrolytic enzymes on rumen degradation kinetics in buffalo bulls. Int. J. Vet. Sci. 3(4): 236-239.

-Ranathunga SD, Kalscheur KF, Hippen AR, Schingoethe DJ (2010). Replacement of starch from corn with non-forage fiber from distillers grains and soyhulls in diets of lactating dairy cows. J. Dairy Sci. 93: 1086-1097. https://doi. org/10.3168/jds.2009-2332

- Roubík H, Mazancová J, Phung LD, Banout J (2018). Current approach to manure management for small-scale Southeast Asian farmers - Using Vietnamese biogas and non-biogas farms as an example. Renew Ener. 155: 362-370. https://doi. org/10.1016/j.renene.2017.08.068

-Roubík H, Mazancová J, Phung PD, Dung DV (2017). Quantification of biogas potential from livestock waste in Vietnam. Agro Res. 15(X): 540-552. 
- Santos SA, Filho SCV, Detmann E, Valadares RFD, Ruas JMR, Amaral PM (2011). Different forage sources for F1 Holstein $\times$ Gir dairy cows. Lives Sci. 142: 48-58. https://doi. org/10.1016/j.livsci.2011.06.017

- Schulze AKS, Weisbjerg MR, Nørgaard P (2014). Effects of feeding level and NDF content of grass-clover silages on chewing activity, fecal particle size and NDF digestibility in dairy heifers. Anim. 8(12): 1945-1954. https://doi. org/10.1017/S1751731114002055

- Van Soest PJ, Robertson JB, Lewis BA (1991). Methods for dietary fiber, neutral detergent fiber and non-starch polysaccharide in relation to animal nutrition. J. Dairy Sci. 74: 3583-3597. https://doi.org/10.3168/jds.S00220302(91)78551-2

-Walli TK, Garg MR, Makkar HPS (2012). Crop residue based densified total mixed ration - A user-friendly approach to utilise food crop by products for ruminant production. FAO Anim. Prod. Health. pp. 172.

-Xu J, Hou Y, Yang H, Shi R, Wu C, Huo G, Zhao G (2014). Effects of forage sources on rumen fermentation characteristics, performance, and microbial protein synthesis in Midlactation Cows. Asian Aust. J. Anim. Sci. 27: 667673. https://doi.org/10.5713/ajas.2013.13604 